\title{
THE IMPACT OF TECHNOLOGY ON THE INDUSTRIAL HERITAGE TOURISM ENTERPRISES: CASE OF THE COAL MINE MUSEUM IN ZABRZE
}

\author{
Krzysztof HERMAN \\ Silesian University of Technology, Faculty of Organization and Management, Institute of Economics and \\ Informatics; krzysztof.herman@polsl.pl, ORCID: 0000-0002-3196-9696
}

Purpose: The aim of the paper is to identify modern technologies used in industrial heritage tourism enterprises and to consider the influence of these technologies on the functioning of the enterprise.

Design/methodology/approach: The research process include two stages. First was initial interview and participatory observation, second, depth-in interviews with managers of industrial heritage tourism enterprises.

Findings: Technologies have impact on heritage accessibility and allows better understand the heritage. However, managers must strike a balance between authenticity and technology to satisfy all target groups (adults, children, specialists, families, etc.).

Originality/value: The paper describes the impact of modern technologies on the functioning of a heritage enterprise and areas where this impact is the strongest. The paper is dedicate to managers of heritage enterprises.

Keywords: modern technologies, industrial heritage, heritage presentation, modern technology impact.

Category of the paper: Case study.

\section{Introduction}

The global tourism market today is characterized by rapid development of digital technologies. It started in 1990s when first computer system was used to improve tourism business. Nowadays it seems reasonable to assume that modern tourism agency cannot exist without IT technologies. However, interesting is that not only agencies are based on technology. Museums, cultural institutions, heritage sites or more broadly - tourist attractions use modern technologies to improve management. A tourism enterprises devoid of website, profile on social media or even online shop is now a rarity. New technologies are also used to heritage presentation. Multimedia contents, large-format film projections and mobile applications are 
frequently use as a part of heritage exhibitions. The advantage of this solution is to present often complex industrial processes, historical documents or traditions elements. However, the use of modern technologies is associated with a few issues. First, in which area of activity it is worth to use it. Second, how it will effect on the operation of the company. These issues above made it possible to clarify the goal of this paper.

The aim of the paper is to identify modern technologies used in industrial heritage tourism enterprises and to consider the impact of those technologies on its operating. Goals realization is based on two-stage research. The first stage is an identification the areas of technologies application. To achieve it participatory observation and brief interview were done. The second stage is study the impact of those technologies on tourism enterprises. It required a depth-in interview with managers dealing with tourist routes. The research results are presented in the form of a case study. The article focuses on modern technologies devoid of going into the technical specifications, its protection or ways of exchanging information between the user and the consumer. The article is also not intended to rating used technologies. Such judgment requires more extensive research. Firstly, an attempt is made to understand what technologies is and to show what kind of technologies are used by tourist enterprises.

\section{Technologies in tourist attractions}

Technology has made our lives much easier. One need only think of the invention of the Internet, e-mail or mobile phones. Technologies make it practically possible to remove barriers of the amount, collected and processed of information (Witczak, 2013). To understand what the technologies really are, it is necessary to refer to literature. Technology is commonly understand as a combinations of things and utility. It is confirmed by Kumar et. al (1999) who define technology as a composition of two primary components - physical (contains products, technics, processes) and informational (know-how, marketing, quality control). A curious instance of technology definition is concept of Reddy and Zhoa (1990). Researchers connect technology with firm-specific information about production process. Technology has been also defined by tourist perspective. For example, Stasiak (2013) describes modern technologies as using IT to create the tourists experience by presentations, tour-guides, audio-visual presentations, multimedia points, websites, mobile devices and virtual or augmented reality. Iwański (2015), in other hand, refers technology to possibility of exchange tourist experiences by websites or social media. Let these above examples suffice to show that technologies are strongly related with enterprises, product and its specification. In tourism are also connected with modern technical solutions. Summarizing above, for the purposes of this paper technology will be taken to mean as all physical elements that are used a modern solutions to improve the enterprises functioning. 
In tourism technologies are strongly connected with improving the quality of tourist services. One of the first technology was used to a computer reservation systems (CRS) which already gained popularity in the 1990s (Archdale, 1993). It allowed to real-time exchanging information about tourism services. However, the real digital revolution began in the 21 st century. The Internet popularization, new methods of communication, devices availability are only a few examples why it started. Today, it is hard to imagine the world devoid of tourism mobile applications (Setten et al., 2004), services like Expedia.com (Lee et al., 2013) AIRbnb (Zervas et al., 2013), Booking.com (Mellinas et al., 2015) or social media. Those all technologies are global. However, interesting are also those technologies that are used inside the tourist attraction because of impact on its functionality.

One of the most important aspect of tourism attractions is safety. It refers to, on the one hand, tourists that are unpredictable and on the other hand, enterprises assets because robberies or devastation. A popular option is closed circuit television (CCTV). E. Beaumont (2002) presents opinion that it is possible to used CCTV to recognition visitors behaviors, not only for the surveillance. Nerngchamnong et al. (2011) suggest that the CCTC could be used as a smart $C C T V$ to that detects the movement and counts the number of tourists who are in the word heritage city. Leão de Brito et al. (2008) are interested in safety as well. Researchers describes wireless sensors which can be used to protect visitors and exhibitions. They focus on technology which integrate location methods and detecting intrusions by aggregating sensor information in real time and providing this information to attractions staff. Last but not least is Radio Frequency Ientification (RFID). This technology is widely used in accommodation services. RFID devices replaced magnetic-stripe security cards for unlocking doors and granting access to secured areas (Want 2004).

As it has been demonstrated above examples are not only a powerful research tool but also practical one. Those technologies are related to safety, but the most recognizable are those technologies that are used to heritage present.

Technologies in heritage presentation are commonly related to use digital projections, multimedia or advanced audio-video systems. One may reasonably suppose that the reason of it is success of The Warsaw Uprising Museum which was built in 2004 (Twoja historia, 2019) and until now it creates a trend in all new exhibitions in Poland. Before 2004 in Poland the most popular technologies was a tour-guide system. Initially, it was the sound-based system, where the content was recorded on cassette tapes, then CDs. However, with the development of technology, audio-visual system with movies, touchable LCD screens or even GPS module were added (Li-Der et al., 2004). Until now the tour-guide systems are used in tourist attraction in whole world and they are the most popular devices.

It is hard to imagine any modern tourist attraction devoid of multimedia contents. Extended information, a combination of sound, image and light make the heritage tempting. Ciurea and Filip (2015) in their publication about innovative museums indicate the advantages of using multimedia. They include the possibility of presenting exhibits with difficult access 
(e.g. delicate exhibits). They also see the opportunity to using such a tool as virtual exhibitions which extending the presented heritage by exhibits or collections owned by other institution. In the opinion of researchers, virtual exhibitions are an excellent opportunity to correlate museum collections located in various cultural units such as museums, libraries, archives and galleries. Their further reflection shows that it can be improve an increase in the number of visitors and the revenue stream.

Other examples of technologies are augmented reality (AR) and virtual reality (VR). Virtual reality may be defined as a computer-stimulated environment in which people interact. For example, environment could be modified in real time by the user actions. In the light of scientific research, VR more than static images acts on the customers. I. Tussyadiah et al. (2018) confirm it and point out a number of benefits of virtual reality for human experience. They list: education through play; personalization; interactivity and full immersion. These features affect the experience of visitors, explaining the main phenomena clearly. However, VR also comes with risks. For example, VR using glasses involves the risk of injury where the real space is not convergent with the virtual space (Choi, Kim, 2017). AR works differently. This technology do not create a reality, but only adds some virtual objects to available space. Interesting research about AR studies were conducted by E. Crammer et al. (2017). They study the potential of AR technology as a value proposition. They notice that there is a lot of support from visitors and stakeholders. Among the advantages that the researchers highlight: an increase in tourist attractiveness, increased revenues and competitiveness. Researchers rightly note the potential offered by AR, however, they assume that the subject of such advanced technology used in tourism requires further scientific penetration (2017).

All of above examples can be used in almost all tourist attractions for heritage presentation. However, there are a lot of technologies that can be used to improve other services. Interesting modern technologies is additive manufacturing, commonly known as 3D printing. In particular, it is associated with the possibility of preserving and presenting valuable historical artifacts. The exhibit image is scanned through technology and then a copy can be made in the form of 3D printing. C. Balletti et al. (2017). points out that 3D printing can be widely used, especially in creating alternative museum exhibitions focused on blind and visually impaired people, recreating missing elements of exhibits or objects, or creating reproductions of exhibits that are souvenirs in a shop.

However, modern technologies in industrial heritage tourism enterprises cannot be discussed without reference to heritage tourism based on industrialization. 


\section{Industrial heritage tourism}

Industrial heritage tourism is a relatively new type of tourism. It comes directly from cultural tourism. G. Richards (2006), describes it as the people movement to cultural attractions with the intention of gathering new experiences and information to providing cultural needs. This form of tourism has been known since antiquity. However, the phenomenon of looking at industry as a cultural attraction appeared in the second half of the 20th century. Initially, this phenomenon was related to operating enterprises (Otgaar 2010), now also its relate to industrial activities like workers' housing estates, thematic museums or even degraded areas (post-mining heaps). In literature, the phenomenon of tourism related to industry is describes differently. Mikos (2008) proposes use a term cultural tourism of industrial facilities, which has relationship with cultural tourism. In literature it is possible to find other describes of phenomena, like more popular industrial tourism (Zawadzki, 2009) or post-industrial tourism (Kruczek, 2016). However, clarifying the terminological dispute is not the purpose of this article. Therefore it was agreed that this phenomenon would be called industrial heritage tourism. This tourism includes industrial heritage tourist attractions. Intuitively, it can be understood as everything that interests tourists and is prepared to receive tourist.

The highest concentration of industrial heritage tourist attractions is in former industrial regions, such as the Ruhr in Germany, the Nord-Pas-de-Calais in northern France, or the Liege in Belgium. In Poland, industrial heritage tourist attractions are concentrated in the Silesia Voivodeship. It results from hard coal deposits and related mines, zinc and iron smelters. Most of the tourist attractions of the industrial heritage of the Silesian Voivodeship are associated on the Industrial Monuments Route. In 2019, there were 42 attraction such as mines, smelters, workers' settlements or museums related to industry or technology. In 2018 they were visited by more than 1 million tourists in total (Szlak Zabytków Techniki, 2019). The number of visitors is growing every year, but to maintain growth, industrial heritage attractions must develop all the time, especially in presenting the heritage (all available ways to represent material and non-material heritage), safety of visitors, their comfort and in general providing tourist needs. To achieve this, it is important to understand what the heritage is. Park (2010) defines heritage as an important element of national history, reminding citizens of their origin, on which a sense of belonging is based. Garrod and Fyall (2000) show the broad significance of heritage and they consider them as a mission of caring for historical property and maintaining it as authentic as possible.

One of the most recognizable industrial heritage sites in Silesia Voivodeship are the Guido Mine and the Queen Luise Adit. Because of quite modern tourist infrastructure, number of tourist routes, number of visitors and differentiation of purposes there were taken as cases for the research. 


\section{Technologies impact on industrial heritage tourism enterprises: the case of the Coal Mining Museum in Zabrze}

Research on the use of modern technologies in industrial heritage tourism enterprises was conducted in two tourist attractions of the Coal Mining Museum in Zabrze (CMM): the Queen Luise Adit and the Guido Mine. The research results present in the form of a case study. They were made in the first half of 2019. Research conducts two stages. First stage is an identification areas of the museum's activity that use modern technologies and it based on preliminary interviews with managers and participant observation. The second stage is to identify modern technologies impact on enterprises and it based on depth-in interviews with managers of those enterprises.

\subsection{Technology in the Coal Mine Museum}

In the first stage of research, an interview was conducted to identify places where modern technologies were used in a tourist attraction. Managers pointed six areas (Fig. 1).

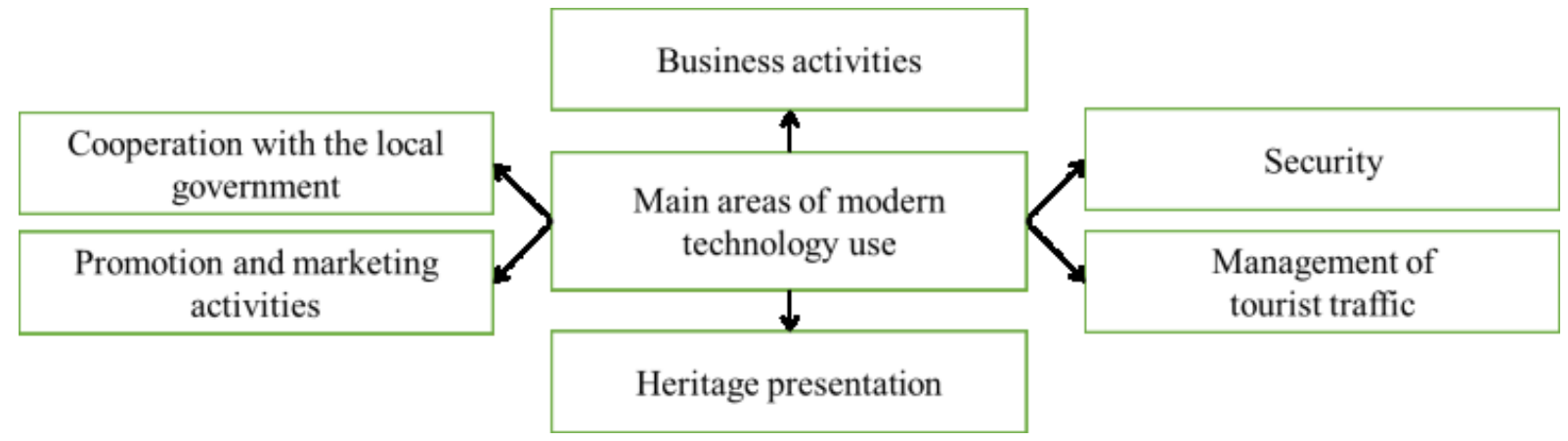

Figure 1. Six areas of modern technology use in the Coal Mining Museum in Zabrze (own work).

The first area is security. It concerns the protection of visitors and goods of the CMM. The basic security system is the CCTV system operated by two units: security company (in the case of tourist service buildings) and dispatcher (in the case of underground tourist routes). Moreover, every mines, including historic mines, are obligate to measure air quality. Therefore, appropriate gas, air flow and content, sensors are installed on each tourist route. In addition in the Guido Mine RFID based system is testing. It will be used to locating visitors in all tourist routes. It is based on RFID tags mounted in helmets using by visitors and detected by underground gates.

The second area is the management of tourist traffic. In the CMM, it requires coordinated action of many units such as a first-line employees, the ticket sales department and the tour guide coordinators. Therefore, special software called the "SORT" (System Obsługi Ruchu Turystycznego - Tourist Service System) was prepared, which enables entering groups in real time, issuing tickets for sale online, selling tickets and accounting work of tour guides as well. 
In CMM's business, managers use commercial software for accounting, product sales and inventory updates as well as document flow, HR and payroll and inventory work.

Next area is cooperation with the local government. It was indicated due to belonging to the Silesian Industrial Monuments Route, managed by the Department of Industrial Heritage Promotion of the Silesian Voivodeship Marshal's Office. Trail members use the internet platform prepared by that local government. It enables the exchange of information between coordinators of tourist attractions, supports joint activities in the promotion and preparation of joint cultural events.

Modern technologies are also widely used in promotion and marketing activities. All tourist products, including information about tourist routes and occasional events, are presented in social media. In addition, there is a website that also offers the option of buying tickets online. Promotional campaigns use multimedia projections and VR glasses that show some of the underground corridors. Particularly noteworthy is the so-called "Periscope" which is a simulation of looking inside the coal mine, using a tube and a mirror system.

The greatest amount of modern technologies has been noticed in heritage presentation. They complement each other with second strongly group: mining machinery and devices. Accordingly, three groups of expositions were selected. The first was operating mining machinery and devices, second, places where modern technologies are used and third, the other (place interpreted only by a guide).

In the Guido Mine $52^{1}$ expositions were identified on three tourist routes. $30.77 \%$ of them use elements supporting the tour guide's narrative. These include working mining machines (13.46\%) and exhibits that used modern technologies (17.31\%). Other expositions are discussed by guides $(69.33 \%)$. Data are presented in Table 1 .

\section{Table 1.}

Expositions in the Guido Mine

\begin{tabular}{|c|c|c|c|c|}
\hline Tourist route & $\begin{array}{c}\text { Number of } \\
\text { exposition }\end{array}$ & $\begin{array}{c}\text { Supported } \\
\text { expositions }\end{array}$ & $\begin{array}{c}\text { Machinery or } \\
\text { devices expositions }\end{array}$ & $\begin{array}{c}\text { Modern technology } \\
\text { expositions }\end{array}$ \\
\hline $\begin{array}{c}\text { Zwiedzanie kopalni } \\
\text { (Visiting the Mine) }\end{array}$ & 37 & $43,24 \%$ & $18,92 \%$ & $24,32 \%$ \\
\hline $\begin{array}{c}\text { Mroki Kopalni } \\
\text { (Darkness Mine) }\end{array}$ & 26 & $8,11 \%$ & $8,11 \%$ & $0,00 \%$ \\
\hline $\begin{array}{c}\text { Szychta } \\
\text { (Work in the mine) }\end{array}$ & 25 & $0,00 \%$ & $0,00 \%$ & $0,00 \%$ \\
\hline
\end{tabular}

Source: own work.

It can be seen from the table 1, the most varied route is Visiting the Mine. 45,24\% of expositions are supported. Modern technology is used in $24,32 \%$ expositions. Other tourist routes are deprived of any modern technology. Machinery or devices are available on two of the tourist routes, Visiting the Mine $(18,92 \%)$ and Darkness Mine $(8,11 \%)$. Work in the mine has non supported expositions. Visiting the Mine has four film projections, that presented

\footnotetext{
${ }^{1}$ Some of the expositions can be found on different tourist routes.
} 
situation in the nineteenth-century mine, one recording explain what mining greetings means, two recordings with motion sensor with loudly sound of devices and two contents dedicate to the Saint Barbara, patron saint of miners (first is multimedia touchable screen, second is so-called "mapping" what is synthetic film projection that use mining chamber as a screen). The tourist route was opened in 2007 and in 2015 was modernized. On Darkness Mine and Work in the mine are no technologically supported expositions which is results of specifications of the presented heritage. Both routes are in places that have been as unchanged as possible. The narrative in these spaces is based on the authenticity and experience of being in a real mine. The routes were available since 2016 .

In the Queen Luise Adit 54 expositions on three tourist routes were identified. 50\% have elements supporting the tour guide's narrative. $33.33 \%$ of expositions are equipped with modern technologies and $25.93 \%$ are with mining machines or devices. Some of the identified stations have both: multimedia content and working mining machines (12.96\%). Data are presented in Table 2.

Table 2.

Expositions in Queen Luise Adit.

\begin{tabular}{|c|c|c|c|c|}
\hline Tourist route & $\begin{array}{c}\text { Number of } \\
\text { expositions }\end{array}$ & $\begin{array}{c}\text { Supported } \\
\text { expositions* }\end{array}$ & $\begin{array}{c}\text { Machinery or } \\
\text { devices expositions }\end{array}$ & $\begin{array}{c}\text { Modern technology } \\
\text { expositions }\end{array}$ \\
\hline $\begin{array}{c}\text { Trasa Turystyczna } \\
\text { (Regular route) }\end{array}$ & 29 & $51,72 \%$ & $24,14 \%$ & $37,93 \%$ \\
\hline $\begin{array}{c}\text { Trasa Rodzinna } \\
\text { (Family route) }\end{array}$ & 20 & $60,00 \%$ & $40,00 \%$ & $25,00 \%$ \\
\hline $\begin{array}{c}\text { Trasa Wodna } \\
\text { (Water route) }\end{array}$ & 25 & $36,00 \%$ & $8,00 \%$ & $32,00 \%$ \\
\hline
\end{tabular}

* Some of expositions have both form.

Source: own work.

All tourist routes in the Queen Luise Adit have expositions using modern technologies. The highest percentage is observed on the Regular route $(37,93 \%)$. There were identify eight film projections about the nineteenth-century mining, the movement of twentieth-century mining machinery, geology and a part of a film from the 1950s, 'Stars must burn' which was made in corridors of the Queen Luise Adit. In addition, on tourist route is one record related to child labor in industry. The route was established in 2017 with the completion of the Main Key Hereditary Adit revitalisation.

On the Family Route 25,00\% expositions are supported by modern technologies and include computer created animation which explains how machines works in real coal mine. On the family route there are also educational lessons for students of all types of schools. For them the multimedia touchable screen with games and plays are prepared. The Family Route has been available after revitalization since 2016.

Water Route is the newest product offered by the CMM. It was opened in 2018 and its main element is over a kilometer rafting by boat trough the Main Hereditary Key Adit. The technologies used on this route are primarily focused on the history of drilling an adit and 
characterizing the phenomena of traditions and mining techniques. On the route film projections dominate. Interesting is an installation that is dedicated to the water dangerous in mines. It imitates water that suddenly flows into the mine gallery. In addition to visual and auditory experiences, the installation has been supplemented with a sprinkler, pouring water on a group of tourists. On the line between modern technologies and an innovative approach to expositions is an installation that shows a fire at the mine. It is a combination of heat radiators, smoke generators and properly arranged light that allows tourists to experience being in dangers area. However, the most extensive installation is the water route, which overcome by boat offers alternating experiences related to film projections, sound and the play of lights. It mainly includes the history of characters known from the stories and legends of Upper Silesia.

In the light of the above considerations and research effects, the identified expositions can be grouped into categories depending on their nature. The proposed typology is shown in Table 3.

Table 3.

Exposition typology in CCM tourist routes

\begin{tabular}{|c|c|c|c|}
\hline \multicolumn{2}{|c|}{ Character of expositions } & \multicolumn{2}{|c|}{ Percentage participation in total expositions } \\
\hline \multicolumn{2}{|c|}{ Area of heritage } & \multicolumn{2}{|c|}{$59,43 \%$} \\
\hline \multirow{2}{*}{$\begin{array}{l}\text { Working } \\
\text { machines }\end{array}$} & Machines and devices & $16,04 \%$ & \multirow{2}{*}{$17,92 \%$} \\
\hline & Reconstructed machines and devices & $1,89 \%$ & \\
\hline \multirow{4}{*}{$\begin{array}{l}\text { Modern } \\
\text { technologies }\end{array}$} & Film projections with speaker & $4,72 \%$ & \multirow{4}{*}{$20,75 \%$} \\
\hline & Additional film projections & $4,72 \%$ & \\
\hline & Multimedia touchable screens & $1,89 \%$ & \\
\hline & Recording stands & $4,72 \%$ & \\
\hline \multicolumn{2}{|c|}{ Combinative installations } & \multicolumn{2}{|c|}{$3,77 \%$} \\
\hline \multicolumn{2}{|c|}{ Multivariate installations } & \multicolumn{2}{|c|}{$2,83 \%$} \\
\hline
\end{tabular}

Source: own work.

The first category is an area of heritage. This category of expositions includes places where the tour guide talks about space around and the main elements are exhibits. Working machines and devices are the second category. Two subcategories were selected in them. Industrial machines and devices (16.04\%) and reconstructed machines $(1,89 \%)$ which were made on the basis of historical documents (for example: 19th century underground port crane). Among the technologically supported positions, the most numerous group are those using modern technologies (20.75\%). This group include film projections with speaker $(4,72 \%)$, additional film projections $(4,72 \%)$, multimedia touchable screen $(1,89 \%)$ and recording stands $(4,72 \%)$. The fourth category is combinative installations (3.77\%), which are also equipped with working mining machines and film projections with a commentary on the operating principles. The last identified category are multivariate installations that are a combination of modern technologies and innovation. These group include installations that allow to feel the specific conditions of industrial space. It use all available technologies (like imitation of fire in mine). 
The identification of modern technologies makes it possible to study their impact on the functioning of the industrial heritage tourism enterprise. To achieve it the depth-in interviews with managers were done.

\subsection{Impact of modern technology on industrial heritage tourism enterprise functioning}

Managers noted that the impact of modern technologies on industrial heritage tourism enterprise can be seen in three categories. The first are those technologies that are necessary for tourist routes, and devote of its tourist traffic may be stopped. The second category is with those technologies whose lack reduces the functionality of the enterprise, e.g. through temporary changes in the organization of tourism. The third category are assistive technologies that do not affect the functioning of the enterprises. All categories are presented on fig 2.

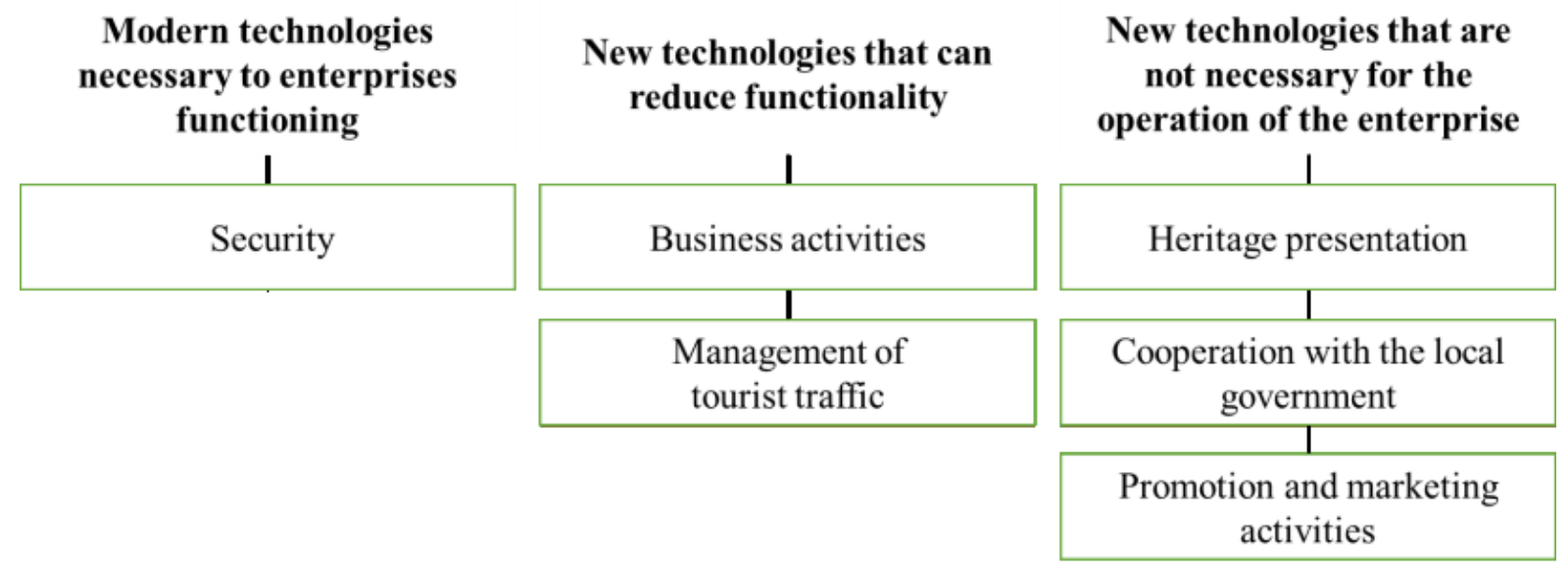

Figure 2. Categories of impact of modern technologies on industrial heritage tourist enterprises functioning.

Stopping the work of the CMM is related to safety. Problems with air quality or vertical transport machines software is a reason to close touristic route. In first case failure of air sensors may result in indicating incorrect values, it can be dangerous for people's health and life. Second case is related to the Guido Mine. Tourist traffic can be stopped as a result of failure of the software monitoring the parameters of the hoisting machine which is responsible for transporting people to the mine and back.

Reduce the industrial heritage tourism enterprise functionality may result from the failure of IT systems that are need to sale products and services. In this case may be temporary problem with selling e.g. tickets on the tourist route, souvenirs in tourist shops or food at gastronomic points. In addition, after SORT failure it can be problem with tour guides and trips connections.

Other technologies are not so important for the functioning of the enterprise. Failure of multimedia projection or mining machine does not affect tourist traffic. Heritage presentation can be discussed without running the multimedia installation. In the case of the communication platform between the local government and the company, alternative methods of 
communication are used. In the case of technical problems with elements used in marketing and promotion, they are omitted or replaced.

Although the impact of modern technologies, especially those related to heritage presentation, does not directly affect the functioning of the enterprise, it is important for the reception of the enterprise by the visitors. To many problems with modern technology like missing multimedia touchable screens, broken film projections or not available recording stands could be interpreted as worthless or low quality.

During the research, attention was also paid to the positive and negative aspects of using modern technologies. The disadvantage is the high cost of installations, which are often impossible to cover from current operations. In the case of technologies used in mining tunnels, there are additional costs associated with their protection against the negative impact of the mining environment (dust, moisture). Accordingly, multimedia installations are financed from external funds. Another problem is that the technologies must resistant to bad conditions. This requires an individual approach to each installation. In addition, access to expositions is difficult, which is not conducive to repairs.

The most important problem is related to balance between authenticity and modernity. Managers noticed that many of narrative places do not need any modern technologies. Mining space, harsh conditions and tour guide's narrative are sufficient to ensure visitor satisfaction. To put there any installations could be received as artificial.

Managers gave also opinion that modern technologies get a major opportunity for people with disabilities. With use of it is possible to show industrial heritage from different ways. For example, multimedia content can be useful for: blind people because of records; people in a wheelchair because virtual tourist route; deaf people because of picture and texts.

Managers also noticed many positives of modern technologies use in industrial heritage enterprises. First is streamlining processes. Business management, especially in the field of security and organization of tourist traffic has become more convenient and their reactions to disorders are almost immediate. In the case of heritage presentation, the unlimited capacity of expositions was considered as a positive aspect. On the one hand, it can be present countless amounts of information, and on the other, it can be for each group of recipients like foreign languages or children. An important element is the increase in the attractiveness of heritage. Managers notice this especially in the context of the young generation, which increasingly requires more stimuli. Moreover, modern technologies and the ability to combine many presentation techniques together can better explain frequently complex industrial processes. 


\section{Conclusions}

During research on the impact technologies on industrial heritage tourism enterprises, it could be noticed that the modern technologies have the same impact on an enterprise as an enterprise on technology. Nowadays it is hard to imagine modern enterprises without modern technologies. As has been shown in research there are in tourist attraction technologies which, on the one hand, are necessary to enterprises working, and on the other hand, they improve the operation of the company and diversify expositions. Research made it possible to draw the following conclusions:

- Technologies have impact on heritage accessibility. For example, the same content may be available in different languages. This allows access for visitors who do not speak languages known by the tourist service and provide them access to knowledge about the heritage.

- With technology is possible to present complex industrial processes or visualize history, which allows better understand the heritage.

- Dust or moisture have negative influence on digital technologies. It is important to use special protection system to save the utility.

- Managers must strike a balance between authenticity and modern technology to satisfy all target groups.

Recognition of modern technologies used in industrial heritage tourism enterprises and their impact on functioning those enterprises is an introduction to further scientific research. It is planned to conduct research in a wider group of industrial heritage tourism enterprises. In future research, it is particularly worth focusing on industrial heritage presentation. Based on the three basic characteristics of the exhibition: area of heritage, working machines and modern technologies, it is possible to define the tourist route as a digital, machinery or exhibit orientated. Recognizing the orientation of tourist routes is a way to indicate trends which are particularly important in designing and building new touristic routes in existing or emerging industrial heritage tourism enterprises.

\section{References}

1. Archdale, G. (1993). Computer reservation systems and public tourist offices, 14, 1, 3-14.

2. Balletti, C., Ballarin, M., Guerra, F. (2017) 3D printing: State of the art and future perspectives. Journal of Cultural Heritage, 26, 172-182.

3. Beaumont, E. (2002). Using CCTV to study visitors in The New Art Gallery, Walsall, UK. Surveillance \& Society, 3(2/3), 251-269. 
4. Choi, H., Kim, S. (2017). A content service deployment plan for metaverse museum exhibitions - Centering on the combination of beacons and HMDs. International Journal of Information Management, 37, 1519-1527.

5. Christou, E. (2006). Heritage and cultural tourism: a marketing-focused approach. In: M. Sigala, and D. Leslie (Eds.), International Cultural Tourism: management, implications and cases. Oxford: Elsevier, 3-15.

6. Ciurea, C., Filip, F.G. (2015). Validation of a Business Model for Cultural Heritage Institutions. Informatica Economică, 19, 2, 46-56.

7. Cranmer, E., Jung, T., Dieck, M. (2017). The Value of Augmented Reality from a Business Model perspective. e-Review of Tourism Research, 1-4.

8. Garrod, B., Fyall, A. (2000). Managing Heritage Tourism. Annals of Tourism Research, $27,3,682-708$.

9. Iwański, L. (2015). Turystyka jako rynek doświadczeń. Kultura Popularna, 2(44), 28-38. DOI: $10.5604 / 16448340.1189301$.

10. Kruczek, Z., Kruczek, M. (2016). Post-Industrial Tourism as a Means to Revitalize the Environment of the Former Oil Basin in the Polish Carpathian Mountains. Pol. J. Environ. Stud., 25, 2, 895-902.

11. Leão de Brito, L., Peralta, L., Santos, F., Fernandes, R. (2008). Wireless Sensor Networks Applied to Museums' Environmental Monitoring. The Fourth International Conference on Wireless and Mobile Communications.

12. Lee, H., Guillet, B., Law, R. (2013). An Examination of the Relationship between Online Travel Agents and Hotels: A Case Study of Choice Hotels International and Expedia.com. Cornell Hospitality Quarterly, 54(1), 95-107.

13. Li-Der, C., Ching-Chao, L., Ming-Yu, L., Chun-Yen, C. (2004). A Tour Guide System for Mobile Learning in Museums. Proceedings of the The 2nd IEEE International Workshop on Wireless and Mobile Technologies in Education.

14. Mellinas, J., María-Dolores S., García J. (2015). Booking.com: The unexpected scoring system. Tourism Management, Volume, 49, 72-74.

15. Mikos (2008). Turystyka kulturowa. Fenomen. Potencjał. Perspektywa. Gniezno: GWSH "Milenium".

16. Nerngchamnong, K., Kaviya, S., Fujii, Y. (2011). World Heritage City Surveillance System by a Smart CCTV System. Procedia Engineering, 8, 321-327.

17. Otgaar, A. (2010). Industrial Tourism - Where the Public Meets the Private. PhD Series in Research in Management.

18. Park, H. (2010). Heritage tourism: Emotional Journeys into Nationhood. Annals of Tourism Research, 37, 1, 116-135.

19. Setten, M., Pokraev, S., Koolwaaij J. (2004). Context-Aware Recommendations in the Mobile Tourist Application COMPASS. In: P. Bra, W. Nejdl, Adaptive Hypermedia and 
Adaptive Web-Based Systems (pp 235-244). Third International Conference, Eindhoven, The Netherlands.

20. Stasiak, A. (2013). Produkt turystyczny w gospodarce doświadczeń. Turyzm, 23, 29-38.

21. Szlak Zabytków Techniki, Available online https://zabytkitechniki.pl, 22.7.2019.

22. Tussyadiah, I., Dan, W., Jung, T., Dieck, M. (2018). Virtual reality, presence, and attitude change: Empirical evidence from tourism. Tourism Management, 66, 140-154.

23. Twoja historia, Available online https://twojahistoria.pl/2017/12/30/pierwsze-takiemuzeum-kulisy-powstania-muzeum-powstania-warszawskiego /\#2, 22.7.2019.

24. Want, R. (2004). RFID: A Key to Automating Everything. Scientific American, 290/1.

25. Witczak, O. (2013). Nowe media w budowaniu marki i wizerunku przedsiębiorstwa. In: A. Bajdak (Ed.), Komunikacja marketingowa. Współczesne wyzwania i kierunki rozwoju (pp. 80-97). Studia Ekonomiczne Uniwersytetu Ekonomicznego w Katowicach, 140. Katowice: Wydawnictwo Uniwersytetu Ekonomicznego.

26. Zawadzki, P. (2009). Znaczenie turystyki industrialnej dla rozwoju oferty turystycznej na przykładzie gminy Polkowice. Prace Naukowe Uniwersytetu Ekonomicznego we Wrocławiu, 50, 253-261.

27. Zervas, G., Proserpio, D., Byers, J.W. (2013). The Rise of the Sharing Economy: Estimating the Impact of Airbnb on the Hotel Industry. Boston University School of Management Research Paper Series, 16, 1-45. 